Institute of $\mathbf{F}_{\text {ood and }} \mathbf{A}_{\text {gricultural }} \mathbf{S}_{\text {ciences }}$

\title{
Manual de los Reglamentos del Agua de Florida: Acta Federal de Insecticidas, Fungicidas, y Rodenticidas ${ }^{1}$
}

\author{
Michael T. Olexa, Laura Minton, Dulcy Miller, y Sarah Corbett ${ }^{2}$
}

\section{Agradecimientos}

Los autores agradecen a Richard Budell de la Oficina de Política del Agua Agrícola del Departamento de Agricultura y Servicios al Consumidor de Florida. Los autores también agradecen a David H. Hammonds, Consultor del Programa de Salud Ambiental, Oficina de Programas de Aguas de Drenaje en el Sitio, del Departamento de Salud de Florida, y a Edward A. Bettinger, Consultor del Programa de Salud Ambiental, Oficina de Programas de Agua del Departamento de Salud de Florida.

\section{Sinopsis}

El Acta Federal de Insecticidas, Fungicidas y Rodenticidas (AFIFR) fue originalmente aprobada en 1947 y significativamente reformada en los 1970s y en 1988, para regular todas las fases de la venta, uso, manejo y eliminación de plaguicidas. En 1996, el Acta de Protección de Calidad de Alimento(APCA) fue reformado otra vez por el AFIFR, especialmente los procesos de establecer las tolerancias para residuos de plaguicidas en los alimentos y en el forraje para el ganado.

1. Este es el documento EDIS FE069, una publicación del Department of Food and Resource Economics, Florida Cooperative Extension Service, Institute of Food and Agricultural Sciences, University of Florida, Gainesville, FL. Publicada Noviembre 2002. Por favor visite la página electrónica EDIS en http://edis.ifas.ufl.edu.

2. Michael T. Olexa, es profesor del Department of Food and Resource Economics, Florida Cooperative Extension Service, Institute of Food and Agricultural Sciences, University of Florida, Gainesville, FL; y miembro de Florida Bar; Presidente de Agricultural Law Committee of The Florida Bar; y Director del Agricultural Law Center. Laura Minton, Dulcy Miller, y Sarah Corbett son estudiantes graduadas de Levin College of Law, University of Florida, Gainesville, FL. Filiberto Reyes-Villanueva fue el traductor de la versión en ingles al español.

Esta publicación esta diseñada para proporcionar información precisa, actualizada y autorizada sobre esta material. Sin embargo, ya que las leyes, reglas administrativas y decisiones de la corte, sobre las cuales están basados, están sujetas a revisión constante; algunas partes de esta publicación podrían ser obsoletas en cualquier momento. Esta publicación es distribuida bajo el entendimiento que los autores no están involucrados en ninguna representación legal u otros servicios profesionales, y que la información contenida aquí no debe ser considerada como un substituto de una asesoria legal. Esta publicación no esta completa en proporcionar toda la información para lograr el cumplimiento de las leyes y reglamentos que gobiernan la protección del agua. Por estas razones, el uso de estos manuales por cualquier persona constituye un acuerdo para mantener libre de daño a los autores, al Florida Cooperative Extension Service, al Institute of Food and Agricultural Sciences, y a la University of Florida por cualquier demanda por responsabilidad de daños, o gastos en que pueda incurrir cualquier persona, como un resultado de hacer referencia o confianza sobre la información contenida en esta publicación. Esta publicación fue apoyada financieramente por el Florida Department of Agriculture and Consumer Services.

EI Instituto de Alimentos y Ciencias Agrícolas es Un empleador que opera bajo Acción Afirmativa y provee Oportunidades Igualitarias, dedicado a promocionar la investigación, a información educativa y otros servicios, únicamente a los individuos e instituciones que operan baj discriminación sin considerar color, raza, sexo, edad, incapacidad u origen. Para más información sobre como obtener otras publicaciones de la extensión, comuníquese con la oficina de Servicio de Extensión de su condado. Servicio de Extensión de la Florida / Instituto de Alimentos y Ciencias Agrícolas / Universidad de la Florida / Christine Taylor Waddill, Decana. 


\section{Definiciones}

\section{Plaguicida}

Plaguicida es ampliamente definido dentro del significado de AFIFR, esencialmente como una sustancia usada para regular, prevenir, repeler o destruir cualquier plaga o planta.

\section{Plaga}

Plaga incluye insectos, roedores, nematodos, hongos, malezas, plantas terrestres y acuáticas, virus, bacterias y cualquier otro organismo viviente, que la Agencia de Protección Ambiental (APA) designe como plaga.

\section{¿Quien Hace Cumplir el AFIFR?}

AFIFR esta administrado por la APA, pero especifica que los estados son los que tienen la responsabilidad primaria del cumplimiento, si ellos demuestran a la APA, que han adoptado adecuadas regulaciones y mecanismos para su ejecución. Florida a entrado en varios acuerdos cooperativos con la APA y ahora comparten responsabilidades para permitir la evaluación y entrenamiento a los candidatos productores. En esta áreas, la APA tiene ahora una posición de supervisora. Sin embargo, el registro y monitoreo de los productores de plaguicidas es todavía regulado totalmente por la oficina central de la APA.

\section{¿Qué Significan las Etiquetas de un Plaguicida?}

Uno de los aspectos mas significativos de AFIFR es el cuerpo de requisitos del etiquetado. Bajo el Acta, los plaguicidas deben ser etiquetados con lo siguientes:

- los ingredientes.

- instrucciones para su uso.

- numero de registro de la APA.

- todas las restricciones y advertencias necesarias.
El AFIFR exige el cumplimiento estricto de las instrucciones impresas en todas las etiquetas. Los cambios en el etiquetado deben reunir los requerimientos del Instituto Nacional de Seguridad Ocupacional y Salud.

\section{¿Qué Plaguicidas Necesitan Registro, Licencia y/o Permiso?}

El AFIFR exige que todos los plaguicidas sean registrados por la APA antes que ellos puedan ser vendidos o usados. El registro de un plaguicida procede cuando este se aplica ampliamente y no tiene efectos adversos en el medio ambiente. Si los tiene, la cancelación o suspensión del registro de ese plaguicida es inmediata. El registro de un plaguicida puede ser cancelado por la APA, si el fabricante falla en su renovación de registro, o si la APA determina que es dañino. Sesenta días después de la fecha limite, el administrador puede cancelar el registro o la licencia de un plaguicida.

Los estatutos pueden imponer condiciones adicionales sobre el uso del plaguicida, donde se encuentren problemas especiales relacionados con su uso.

\section{Plaguicidas de Uso General}

Los plaguicidas de uso general pueden ser aplicados por cualquiera y no se requiere permiso, aunque el usuario debe todavía cumplir con los requisitos del etiquetado y otras regulaciones.

\section{Plaguicidas de Uso Restringido}

Los requisitos de uso restringido pueden ser aplicados por tres diferentes categorías de aplicadores:

1. Los aplicadores privados son quienes aplican plaguicidas para tener una producción agrícola en sus propias tierras bajo su control. Los aplicadores deben estar atentos a las restricciones reguladoras para evitar efectos adversos sobre el medio ambiente. Los aplicadores privados deben tener licencia para usar plaguicidas.

2. Los aplicadores comerciales son quienes aplican plaguicidas a tierras de otras personas a cambio de un pago. Estos también requieren tener licencia. 
3. Los aplicadores de uso experimental son usualmente fabricantes o investigadores que requieren de un permiso para uso experimental, y probar un plaguicida no registrado y así obtener datos para apoyar su registro.

\section{Los aplicadores de uso restringido deben tener} registros comparables a los aplicadores comerciales. El estado puede exigir un entrenamiento mínimo especifico para todos los aplicadores.

Cada categoría permitida esta sujeta a exámenes y procedimientos de certificación separados, y puede estar sujeta a diferentes castigos por las violaciones.

\section{¿Cuáles son los Castigos?}

Los aplicadores comerciales, proveedores mayores o menores, o distribuidores que violen el acta o sus permisos, están sujetos a multas civiles de hasta $\$ 5,000$ por ofensa. Los castigos civiles no pueden ser impuestos contra estas partes sin una audiencia. Ellos también están sujetos a castigos penales de hasta $\$ 25,000$ y un año de prisión cuando estén conscientes de las violaciones.

Los aplicadores privados tiene derecho a una advertencia escrita, pero subsecuentes violaciones pueden ser castigadas por una multa de hasta $\$ 1,000$. Si conocen las violaciones pueden ser objeto de multas penales de $\$ 1,000$ y 30 días de prisión.

Los productores de plaguicidas, registradores y los que solicitan registros que deliberadamente violen el AFIFR, están sujetos a multas penales de hasta $\$ 50,000$ y un año en prisión. Sin embargo, ningún derecho privado a la acción existe bajo las regulaciones de AFIFR. Los empleadores pueden también ser procesados por violaciones de sus empleados o agentes que actúan bajo su nombre.

Los violadores de AFIFR pueden también estar sujetos a castigos bajo el Acta Federal de Alimentos, Drogas y Cosméticos, el Acta de Conservación y Recuperación de Recursos y el Acta de Salud y Seguridad Ocupacional.

\section{Acta de Protección de Calidad de Alimentos}

En 1996, el Acta de Protección de Calidad de los Alimentos (APCA) reformo la AFIFR, respecto a los procesos de establecimiento de tolerancias para residuos de plaguicidas, en alimentos y forraje para el ganado. El APCA representa el cambio mas grande en el sistema y procesos de plaguicidas federales, nunca antes realizados. Las obligaciones de APCA incluye:

- establecer un nuevo estándar de seguridad conveniente cuando se establezcan tolerancias de una razonable certeza de no daño a causa de una exposición total.

- obligar que todas las tolerancias existentes sean reafirmadas bajo el nuevo estándar.

- la APA exige hacer una determinación explicita de las tolerancias para que los residuos en alimentos sean seguros para los niños.

\section{Fuente}

Código 7 de los Estados Unidos secciones 136 a $136 y$. 